\title{
TNFRSF8 Gene Product
}

National Cancer Institute

\section{Source}

National Cancer Institute. TNFRSF8 Gene Product. NCI Thesaurus. Code C103889.

A protein encoded by the TNFRSF8 gene. 